臨床耳㽞：第7卷・第2號・ 1996

Clin. Otol. pp 232 241

Vol. 7, No. 2, 1996

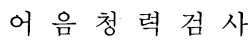

춘해병원 이비인후과

이 종 담

\title{
Speech Audiometry
}

Jong Dam Lee, M.D.

Department of Otolaryngology, Chun Hae Hospital, Pusan Korea.

서 론

사람의 청력은 서로의 말을 듣고 의사전달을 하여 서로가 이해하는 일상생활에 가장 기초 적이고 중요한 역할을 한다. 물론 음악을 들어 정서적 감성을 풍부하게 하고 생활 주변에서 나는 여러 가지 소리를 들어 우리 생활에 도 움을 주어 더욱 편리하게 하기도 한다. 이비인 후과에서의 청력검사는 순음청력검사(純音聽 力檢査 pure tone audiometry)가 기본적 검사 이고 그 외 어음청력검사, 고막운동(탄성)검사 (tympanometry), 뇌파청 력검사(腦波聽力檢査) 등이 보조적으로 검사하고 있으며 각 목적에 따라 검사방법을 선택한다. 어음청력검사는 순 음청력검사와 더불어 기타 여러 검사와 병행 하여 전음성난청(傳音性難聽 conductive hearing loss)의 감별진단, 사회적응능력, 보청기 착용의 지침, 청력증진수술의 적웅 동을 알기 위하여 실시되며 검사용 어음의 선택, 어음표, 어음청취역치(語音德取閾値 speech reception threshold), 어음명료도(語音明瞭度 speech discrimination score) 검사법, 어음청력검사에
영향을 미치는 인자 등에 관해서 논한다.

1. 어음청력검사의 임상적 목적(clinical purpose of speech audiometry)

1) 청력장애의 부위별 진단의 보조적 역할; 어음청력검사나 순음청력점사 만으로는 난청 진단에 제한이 있다. 양 검사를 다 같이 실시 하여 그 난청의 해부학적 부위진단이 가능해 진다. 즉 전음성난청 (傳音性難聽 conductive hearing loss), 감각신경성난청 (感礐神經性難 聽 sensorineural hearing loss)의 진단에는 순 음청력검사만으로도 가능하나 감각신경성난청 중에서도 그 장애부위가 와우(蝸牛 cochlea)에 있느냐 후미로(後迷路 retrocochlear)냐의 감 별진단에는 어음청력검사가 큰 도움이 된다. 즉 후미로성난청은 예컨대 청신경종(聽神經腫 acoustic neuroma)같은 것은 순음청력검사 성 적은 비교적 양호하나 어음명료도는 $30 \sim 40 \%$ 정도밖에 되지 않는 수가 많다. 일반적으로 감 각신경성난청에서는 어음명료도가 $70 \sim 80 \%$ 를 넘지못하는 수가 많다.

2) 사회적응능력의 평가; 어음명료도검사

KEY WORDS : Word selection - Speech reception threshd Discrimination score. 
는 그 개인의 청력이 얼마나 사희 적응이 가 능한가를 알려준다. 사회적응능력을 측정하는 데는 일정한 기준이 없으나 일반적으로 사회 적응지수(前會適應指數 social adequency in$\mathrm{dex}$ 로 추정하는 수가 많다. 이 사회적응지수 의 산출은 Davis 등 ${ }^{18)}$ 은 단음절(monosyllabic word)로 검사한 정상청력의 어음청취역치 (SRT)에 20,35 , 및 $50 \mathrm{~dB}$ 를 더한 강도에서 명료도를 검사한다. 즉 한국어음표로써는 단음 절(單音節 monosyllabic word)은 $30 \mathrm{~dB}, 2$ 음절 (二音節 bisyllabic word)) 은 $20 \mathrm{~dB}$ 이므로 55 $\mathrm{dB}$ (faint sound), $70 \mathrm{~dB}$ (average sound) 및 85 $\mathrm{dB}$ (loud sound)에서 각각 어음명료도를 검사 하여 이 세 명료도의 산술평균치를 사회적응 지수로 하였으며 이수치가 94 이상이면 정상이 고 곤란을 느끼기 시작하는 상한선이 67 , 부적 합한 하한선이 33 , 언어생활불능이 $10 \sim 15$ 라고 하였다.

3) 청력증진수술의(tympanoplasty) 적응 결정; 전음성난청은 순음청력검사와 임피단스 청력검사 만으로도 진단이 가능하다. 그러나 수술 후 기-골도차(氣一骨導差 A-B gap)가 개선된다고 해서 어음명료도가 개선된다는 증 거는 없다. 즉 어음명료도검사를 해야 술후 회 화능력의 개선여부를 예측할 수 있다.

4) 보청기(補聽器 hearing aid)의 선텍 지 침; 청력재활은 보청기를 장착하는 것으로 어 음청력검사가 반드시 이루어져야 한다. 즉 본 검사로 회화의 결점이 어디에 있는지 무엇을 얼마나 듣고 얼마나 이해하는지를 알려준다. 역학범위(dynamic range)는 보청기의 사용범 위를 알려주며 보청기의 증폭은 최고명료도 (maximal discrimination score)까지 높여야 하 나 불쾌음량(uncomfortable level; UCL)까지는 가지 않아야 하며 그 한계도 어음청력검사로써 알 수 있다. 한편 이 어음청력검사는 보청기 착용이 얼마나 어려운가를 알려주기도 한다. 즉 명료도가 불량하거나 역학범위가 좁거나 하면 보청기의 가용범위가 좁아 그 효과를 내 기가 대단히 어럽다. 이런 경우는 청각훈련 (auditory training)이 필요하다.

\section{2. 어음청력검사(語音聽力檢査}

speech audiometry)에 상용되는 단어 언어

(言語)는 각 나라마다 다르므로 각 나라에 표준화된 검사용 어음 표가 준비되어 있어야 한다. 우리 나라에서는 아직 통일된 어음 표는 없으나 그 간의 어음청력검사에 관해서 연구 발표된 것은 신 ${ }^{10)}$ 함 ${ }^{17)}$, 유$^{12)}$, 명 등6), 유 ${ }^{11}$, 이 ${ }^{14)}$, 이 등 ${ }^{8}$, 김 등 ${ }^{2)}$ 한 등 ${ }^{16)}$, 김1), 김 등 ${ }^{4}$, 윤 등 ${ }^{13)}$, 등이 있다.

어음청력검사에 사용되는 것은 단어(單語 word)와 문장(文章 sentence)이 있고 단어 중 에는 단음절(單音節 monosyllabic word)과 이 음절(二音節 bisyllabic word)이 많이 사용되며 3 음절 4 음절 그리고 문장 등은 특별한 경우에 사용된다.

어음청력검사용 단어의 조건은 (1) 일상생 활에 친숙한 쉬운 단어를 선택하고, (2) 단음 절 단어는 각 단어의 발성시의 강도가 동일하 도록 선택하는 발성학적 동일음압단어(發馨學 的同一音㗨單語 phonetically balanced word; $\mathrm{PB}$ word)라야 하고 (3) 2 음절 단어(bisyllabic word)는 발성학적으로 양 음절의 강도(음압) 가 동일한 양양격단어(揚揚格單語 spondiac word)를 선택해야 한다. (4) 검사용 단어는 표 1 과 같이 50 개 단어씩 표를 작성하여 사용하 는데 각 표마다 동일난이도(同一難易度)라야 하고 (5) 음성학적부동성 (音馨學的不同性 phonetic dissimilarity) 즉 단어의 각 음소(音 素 phoneme)가 각 표마다 동일 비율로 포함 되도록 한다.

문장(文章 sentence)은 단어검사로는 검사 가 잘 되지 않는 경우에 사용하며 문장선택도 단어 선택과 같은 조건으로 선택한다. 즉 일상 생활에 많이 쓰이는 문장을 선택하는데 10 개 문장을 한 표로 작성한다. 각 문장에는 50 개의 표적단어(標的單語 key word)를 넣어 의문문 (疑問文 interrogative sentence), 서술문(敍述 文 declarative sentence) 그리고 명령문(命令 文 imperative sentence)을 사용하여 검사하며 핵심단어의 인지도에 따라 그 성적을 결정한다 (Davis and Silverman, 1978 ${ }^{18)}$ ). 
문장검사를 일상 생활환경과 같은 조건하에 검사하는 소음하 어음청춰검사(騷音下語音聽 取檢査; speech reception in noise)를 하는 것 으로 문장은 반은 섭게 이해할 수 있는 것과 반은 이해할 수 없는 것 즉 전후관계가 있는 문장 (contextual syntactic)과 음율법상 합당한 암시를 주는 문장(prosodic cues)으로 구성하 며 역시 표적단어의 인지도로 결정한다. 잡음 은 12 인의 각기 다른 속삭임 회화를 혼합하여 (coctail noise) 사용한다(Kalikow et al, 1977 $\left.{ }^{201}\right)$.

각 검사재료에 따른 검사성적은 단어(單語 word)보다 문장(文章)이 더 잘 이해한다. 각 단어 중에서는 음절이 많을 수록 잘 이해한다.
즉 3 음절은 2 음절보다 잘 이해하고 2 음절은 단음절보다 더 잘 이해한다. 단음절 중에는 무 의단어(無意單語 meaningless word)보다 유의 단어(有意單語 meaningful word)를 더 잘 이 해한다.

3. 어음청력검사 어음표 (word list of speech audiometry)

저자가 사용하고 있는 어음 표는 김 ${ }^{1)}$ 이 작 성한 것이며 표 1 과 표 2 와 같다 표 1 은 2 음 절단어표(二音節單語表 bisyllabic word list)로 어음청취역치(語音㯖取閾値 speech reception threshold; SRT)검사용이고 표 2는 단음절단 어표(單音節單語表 monosyllabic word list)로

표 1. 어음청취역차용 어음표

\begin{tabular}{|c|c|c|c|c|c|c|c|c|c|c|}
\hline \multicolumn{7}{|l|}{ 제 1 표 } & & \multirow{2}{*}{$\begin{array}{c}\mathrm{dB} \\
\text { 장군 }\end{array}$} & \multirow{2}{*}{$\overline{\overline{\text { 방송 }}}$} & \multirow{2}{*}{$\begin{array}{r}\% \\
\text { 의 견 }\end{array}$} \\
\hline 첫 째 줄 & 겨울 & 고향 & 세상 & 하늘 & 싸움 & 친척 & 나라 & & & \\
\hline 둘 째 줄 & 병 원 & 큰집 & 불편 & 교통 & 농촌 & 할동 & 계획 & 소원 & 정말 & 필요 \\
\hline 셋 째 줄 & 청년 & 마을 & 유명 & 국군 & 행복 & 통일 & 생각 & 편지 & 대답 & 물건 \\
\hline 네 째 줄 & 민족 & 까닭 & 운동 & 손넘 & 글씨 & 기차 & 귀신 & 외국 & 담배 & 지금 \\
\hline 다섯째줄 & 둘째 & 그늘 & 이 때 & 동생 & 사람 & 신문 & 종류 & 오빠 & 약속 & 안녕 \\
\hline 제 2 표 & & & & & & & & $\mathrm{dB}$ & & $\%$ \\
\hline 첫 째 줄 & 글씨 & 하늘 & 오빠 & 외국 & 통일 & 불편 & 방송 & 계획 & 사람 & 친절 \\
\hline 둘 째 줄 & 병원 & 민족 & 대답 & 신문 & 겨우 & 지금 & 소원 & 활동 & 종류 & 청년 \\
\hline 셋 째 줄 & 필요 & 마을 & 세상 & 고향 & 생각 & 의견 & 물건 & 약속 & 교통 & 장군 \\
\hline 네 째 줄 & 이때 & 손넘 & 농촌 & 나라 & 행복 & 큰집 & 국군 & 동생 & 정말 & 안녕 \\
\hline 다섯째줄 & 기차 & 담배 & 싸움 & 편지 & 유명 & 귀신 & 둘째 & 운동 & 까닭 & 건설 \\
\hline 제 3 표 & & & & & & & & $\mathrm{dB}$ & & $\%$ \\
\hline 첫 째 줄 & 통일 & 지금 & 귀신 & 의견 & 계 획 & 마을 & 필요 & 불편 & 편지 & 병원 \\
\hline 둘 째 줄 & 교통 & 싸움 & 신문 & 청년 & 생각 & 하늘 & 대답 & 약속 & 사람 & 건설 \\
\hline 셋 째 줄 & 행복 & 동생 & 고약 & 유명 & 정말 & 손님 & 활동 & 나라 & 글씨 & 민족 \\
\hline 네 째 줄 & 농촌 & 안녕 & 오빠 & 큰집 & 국군 & 소원 & 겨울 & 방송 & 외국 & 종류 \\
\hline 다섯 째줄 & 이 때 & 세상 & 까닭 & 물건 & 기차 & 운동 & 장군 & 친절 & 둘째 & 담배 \\
\hline 제 4 표 & & & & & & & & $\mathrm{dB}$ & & $\%$ \\
\hline 첫 째 줄 & 물건 & 통일 & 안녕 & 고향 & 필요 & 싸움 & 신문 & 외국 & 의견 & 국군 \\
\hline 둘 째 줄 & 농촌 & 겨울 & 세상 & 방송 & 둘째 & 손넘 & 불편 & 장군 & 기차 & 운동 \\
\hline 셋 째 줄 & 약속 & 병원 & 지금 & 동생 & 이때 & 활동 & 귀신 & 소원 & 담배 & 종류 \\
\hline 네 째 줄 & 오빠 & 마을 & 계흭 & 사람 & 하늘 & 편지 & 글씨 & 까닭 & 친절 & 유명 \\
\hline 다섯째줄 & 건설 & 청년 & 행복 & 큰집 & 교통 & 대답 & 민족 & 생각 & 나라 & 정 말 \\
\hline
\end{tabular}


표 2. 어음명료도용 어음표

\begin{tabular}{|c|c|c|c|c|c|c|c|c|c|c|}
\hline \multicolumn{7}{|l|}{$\mathrm{A}$} & & \multirow{2}{*}{$\begin{array}{l}\mathrm{dB} \\
\text { 벼 }\end{array}$} & & \multirow{2}{*}{$\begin{array}{l}\% \\
\text { 멋 }\end{array}$} \\
\hline 첫 째 줄 & 들 & 뼉 & 쌀 & 봄 & 왕 & 섬 & 산 & & 춤 & \\
\hline 둘 째 줄 & 손 & 분 & 열 & 용 & 탑 & 적 & 예 & 남 & 비 & 왜 \\
\hline 셋 째 줄 & 원 & 곳 & 길 & 횐 & 밀 & 귀 & 강 & 겁 & 집 & 배 \\
\hline 네 째 줄 & 밤 & 댁 & 눈 & 물 & 돈 & 잠 & 형 & 떡 & 뜻 & 쪽 \\
\hline 다섯째줄 & 꾀 & 실 & 칼 & 귤 & 맛 & 법 & 피 & 약 & 총 & 밥 \\
\hline B & & & & & & & & $\mathrm{dB}$ &  & $\%$ \\
\hline 첫 째 줄 & 뜻 & 귤 & 밥 & 예 & 춤 & 물 & 왜 & 손 & 산 & 잠 \\
\hline 둘 째 줄 & 돈 & 봄 & 형 & 충 & 횐 & 왕 & 길 & 곳 & 용 & 밀 \\
\hline 셋 째 줄 & 비 & 맛 & 눈 & 재 & 탑 & 섬 & 댁 & 열 & 실 & 귀 \\
\hline 네 째 줄 & 법 & 분 & 겁 & 피 & 밤 & 약 & 원 & 집 & 들 & 강 \\
\hline 다섯째줄 & 桑 & 적 & 멋 & 빼 & 쌀 & 꾀 & 칼 & 벼 & 남 & 떡 \\
\hline $\mathrm{C}$ & & & & & & & & $\mathrm{dB}$ & - & $\%$ \\
\hline 첫 째 줄 & 총 & 용 & 귤 & 법 & 형 & 밤 & 왜 & 눈 & 손 & 밥 \\
\hline 둘 째 줄 & 약 & 길 & 예 & 열 & 쌀 & 돈 & 맛 & 칼 & 적 & 뼈 \\
\hline 셋 째 줄 & 떡 & 집 & 왕 & 비 & 궈 & 강 & 뜻 & 원 & 배 & 물 \\
\hline 네 째 줄 & 쪽 & 봄 & 곳 & 꾀 & 들 & 잠 & 남 & 벼 & 춤 & 탑 \\
\hline 다섯째줄 & 섬 & 분 & 겁 & 멋 & 피 & 실 & 횐 & 밀 & 산 & 댁 \\
\hline $\mathrm{D}$ & & & & & & & & $\mathrm{dB}$ & 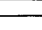 & $\%$ \\
\hline 첫 째 줄 & 뜻 & 원 & 길 & 돈 & 남 & 산 & 귀 & 칼 & 물 & 밀 \\
\hline 둘 째 줄 & 피 & 섬 & 귤 & 밥 & 쌀 & 뼝 & 곳 & 잠 & 탑 & 댁 \\
\hline 셋 째 줄 & 벼 & 봄 & 떡 & 멋 & 왜 & 밤 & 집 & 법 & 비 & 적 \\
\hline 네 째 줄 & 강 & 형 & 열 & 흰 & 눈 & 叒 & 실 & 꾀 & 용 & 총 \\
\hline 다섯째줄 & 들 & 분 & 왕 & 맛 & 손 & 약 & 춤 & 겁 & 예 & 재 \\
\hline
\end{tabular}

어음명료도검사(語音明瞭度檢査 speech discrimination test)에. 적용하는 표이다. 각 표는 각 음소가 모두 균등하게 포함하고 난이도가 균등하게 분포되도록 작성한다.

\section{4. 검사장치(检查裝置 test equipment)}

검사단어는 녹음테이프(錄音테이프 audio tape)나 음반(音艋)에 녹음한 것을 사용하거나 검사자가 직접 발음하는 육성 (live voice; $\mathrm{LV}$ ) 으로 검사한다. 소형녹음테이프(cassette tape) 는 영구보존이 가능하고 재검사가 편리하여 많이 사용하고 있으나 가까운 장래에 레이저 밀집음반(密集音盤 laser compact disc)으로 전환될 것으로 예측한다. 즉 이 것은 더욱 연 구적이고 잡음이 더욱 적으며 사용에 편리하
기 때문이다. 육성검사(肉䠛检査 live voice test)는 융통성이 있어 주의집중이 어려운 어 린이나, 노인, 녹음에 익숙하지 못한 특수인의 검사에 적절히 대처할 수 있고 시간을 조절하 여 편리하게 검사하여 시간 절약이 된다. 그러 나 검사자의 발음에 동질성이 없어 동일조건 으로 재생할 수 없는 것이 결점이다. 발음 자 체에도 검사자마다 달라 그 성적에 차가 있을 수 있다. 이런 점은 녹음테이프나 음반이 좋으 며 동일조건으로 재생되고 표준화되어 있어 재검사할 수 있고 타 기관과의 성적과도 비교 할 수 있다. 그러나 녹음에 익숙하지 못하거나 지능에 장애가 있는 예, 어린이에게는 일정시 간 간격으로 기계적으로 지나가므로 이해할 시간적 여유가 없는 것이 단점이기도 하다. 
검사실은 육성검사에는 2 개의 방음실(防音 室 sound proof room) 즉 피검자가 들어가는 본검사실과 검사자가 육성으로 발음하는 보조 실이 필요하고 녹음테이프로 검사할 때는 반. 드시 2 개의 방음실이 필요하지 않으며 피검자 가 들어 갈 방음실만 있으면 된다. 방음실의 크기는 8 평방 피트(8 feet ${ }^{2} 2.3$ 평)이상이라야 하고 본검사실과 보조실 사이는 2 중 혹은 3 중 의 유리창문으로 만들어 관찰할 수 있게 한다.

어음청력기(speech audiometer)는 대부분 순음청력기(pure tone audiometer)와 겸용으 로 제작된 것이며 여기에 수화기(receiver)를 장착하여 육성으로 혹은 소형녹음기를 연결시 켜 환자에게 들려 줄 회로가 있고 환자가 사 용할 수 있는 송화기(microphone)가 있다. 어 음의 증감은 감쇠기(attenuater)를 사용하는데 순음청력검사 때의 조작과 동일하다.

\section{5. 검사방법(檢査方法 practice of test)}

검사하기 전에 검사방법 검사목적 및 그 순 서 둥을 피검자에게 충분히 설명하여 이해토록 하고 본검사를 하기 전에 충분한 설명과 연습 검사를 하여 검사에 대한 공포감(썬怖感 fear) 이나 불안감(不安感 anxiety)을 없애고 누구라 도 할 수 있다는 자신감을 가지도록 한 다음 충분히 큰 음으로 듣게 하여 대답하는 방법, 그리고 음의 강도가 차차 약해진다는 것이나 또는 강해친다는 것을 이해시킨다. 청력이 좋 은 귀부터 먼저 검사하며 차폐(遮蔽 masking) 가 필요할 때는 이 차폐에 대하여 충분히 설 명하고 몇 번 연습검사을 거쳐 익숙해 진 다음 본검사를 한다. 차폐음은 순음청력검사에 준하 며 백색잡음(白色雜音 white noise), 회화음역 의 대역잡음(帶域雜音 band noise)을 사용한 다.

오디오메터(audiometer)는 전원을 넣고 잠 시동안 기다려 정상가동되도록 가열 (warming up)시킨 다음 녹음테이프를 사용할 때는 이 테이프에 미리 녹음해 둔 $1000 \mathrm{~Hz}$ 를 재생하여 VU meter가 “ 0 "이 되도록 조절하고 육성으로 검사할 때는 검사자가 발음하면서 VU meter가
"0"이 되도록 조절한다. 대부분 오디오메터가 순음검사와 어음검사의 겸용이므로 그 회로를 어음청력검사쪽으로 돌려야 한다. 검사음은 오 다오메터(audiometer)를 통하여 수화기(受話 ⿳⼝丸ㅁ receiver)로 듣게 한다. 보청기의 적정성검 사에는 귀에 착용하는 수화기 대신 큰 확성기 를 통한 검사도 한다. 어음을 듣게 하는 방법 에는 상승법(上昇法 ascending method)과 하 강법(下降法 descending method)이 있다. 하 강법은 충분히 들을 수 있는 음압으로 먼저 검사하고 점차 약하게 하여 검사하는 방법이며 상승법은 그 반대 즉 충분히 들리지 않는 강 도에서 점차 강하게 하여 검사하는 방법이다.

6. 어음청력도(語音聽力圖 speech audiogram)

어음청력검사 결과는 그림 1 과 같이 어음청 력도에 기록한다. 어음청력도는 명료도 $15 \%$ 의 종축의 길이와 $10 \mathrm{~dB}$ 의 횡축의 길이를 동일하 게 그리며 횡축에 음의 강도를 $\mathrm{dB}$ 로 표시하고 종축에는 어음을 정확하게 듣는 명료도의 백 분율을 기록한다.

\section{7. 어음청취역치(語音聽取關值 speech re-} ception threshold; SRT)

어음을 인식하는 가장 낮은 음압을 어음인 식역치(語音認識闘値 speech detection threshold; speech awareness threshold)라 하고 어음을 이해하는 역치 즉 어음을 $50 \%$ 정답하 는 음압을 어음청취역치 (語音㯖取閥値 speech reception(recognition) threshold)라고 하며 약 해서 SRT라고 한다.

어음청취역치는 일상생활에 가장 많이 쓰이 는 친숙한 2 음절 단어(bisyllabic word)를 사용 하는 경우가 가장 많다. 이 단어는 양 음절의 음압이 동일한 양양격단어(揚揚格單語 spon$\operatorname{diac}$ word)로 표 1 과 같다. 각 표마다 50 개 단 어로 된 네 개의 어음표(word list)를 검사자의 임의대로 사용한다.

검사는 주로 하강법 (descending method) 즉 충분히 들을 수 있는 음압으로 먼저 검사하고 


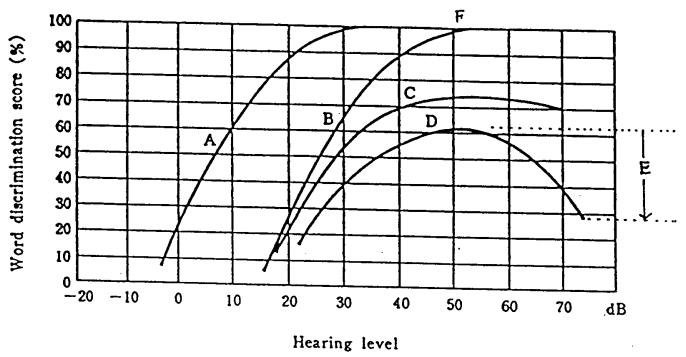

그림 1. 정상 및 난청형에 따른 어음청력도

$\mathrm{A}$. : 정상청력, $\mathrm{B}$ : 전음성난청, $\mathrm{C}$ : 미로성난청, $\mathrm{D}$ : 후미로성난청, $\mathrm{E}$ : Rollover phenomen, $\mathrm{F}$ : 최고명료도.

점차 약하게 하는 방법을 사용한다. 시작음압 은 일반적으로는 순음청력검사(純音聽力檢查 pure tone audiometry)에서 회화음역(會話音 域 speech range)인 500,1000 및 $2000 \mathrm{~Hz}$ 의 3 개 주파수의 평균 역치(threshold)를 기준으로 하든지 3 주파수의 역치 중 청력이 좋은 2 개 주파수의 평균 역치를 기준 하여 이 음역의 평균역치에 $25 \mathrm{~dB}$ 를 더한 음압으로 검사를 시 작한다. 즉 피검자의 회화음역의 평균순음역치 가 $20 \mathrm{~dB}$ 였다면 여기에 $25 \mathrm{~dB}$ 를 더한 $45 \mathrm{~dB}$ 로 시작한다. $3 \sim 4$ 개 단어를 듣게 하여 모두 정확 하게 대답하면 $10 \mathrm{~dB}$ 씩 낮추어 가면서 $3 \sim 4$ 개 단어를 들려주어 검사한다. 4 개 단어를 모두 듣지 못하거나 한 단어만 대답하면 그 음압에 $20 \mathrm{~dB}$ 를 더한 높인 음압으로 검사하여 다시 약하게 하여 검사하여 2 개 단어를 연속 못 들 으면 이번에는 $10 \mathrm{~dB}$ 강하게 하여 다시 검사 한다. 어음청취역치 가까이에서는 $2 \sim 3$ 개 단어 씩 $2 \mathrm{~dB}$ 간격으로 낮추어가면서 검사하며 이 중 2 개를 맞추고 한 개가 틀리면 더욱 $2 \mathrm{~dB}$ 를 낮 추면 3 개단어 중 2 개가 틀리고 한개가 맞게 될 것이다. $50 \%$ 를 맞추는 음압을 알 수 있을 것 이다. 또 4 개 단어 중 2 개를 맞추고 2 개가 틀 렸다면 그 음압이 어음청취역치(語音聽取域値 speech reception threshold; SRT)가 될 것이
다. 이 성적을 그림 1 과 같이 기록한다. 즉 명 료도곡선이 $50 \%$ 선과 교차하는 곳의 강도 $(\mathrm{dB})$ 가 어음청취역치이다.

상숭법(上昇法 ascending method)은 회화음 역의 순음청력 평균역치에서 시작하여 $10 \mathrm{~dB}$ 씩 높여가면서 검사하여 완전 이해할 때까지 검사한 후 다시 $15 \mathrm{~dB}$ 약하게 하여 검사하고, 여기서 $5 \mathrm{~dB}$ 씩 강하게 하면서 $2 \sim 3$ 번 검사하여 $50 \%$ 를 정답하는 음압을 결정한다. 상승법과 하강법과의 차이는 아주 적다. 법률상의 문제 가 있는 예는 상승법과 하강법 모두 검사하고 그 차가 $6 \mathrm{~dB}$ 이상이면 검사자에 문제가 있는 것으로 보아야 하고 다른 방법으로도 검사해야 한다.

편법(수정)어음청취역치 검사법(modification of SRT); 이상과 같은 방법으로 검사가 잘 되지 않을 때는 방법을 바꾸어 검사한다. 즉 어린이에서는 그림책을 주어 들은 대로의 그 림을 지적케 하는 방법, 혹은 성장에 따른 단 어를 제시하여 지적케 하는 방법, 신체의 부분 을 지적케 하는 방법 등으로 검사하며 단어검 사와 본 방법에는 큰 차이가 없다. 대상이 되는 것은 어린이, 뇌성마비, 후두적출환자, 말더듬, 겁이 많은 자, 기타 발음장애자 등에 적용하면 편리하다. 이런 방법으로도 검사가 되지 않으 
면 어음인식역치(語音認識閥値 speech detection threshold)를 측정한다.

$\mathrm{SRT} 0 \mathrm{~dB}$; 어음청취역치 즉 2 음절 단어를 $50 \%$ 이해하는 음압을 SRT $0 \mathrm{~dB}$ 로 하는 것이 다. SRT $0 \mathrm{~dB}$ 는 마국 영어로 정상인에서 검사 한 것은 수화기(ear phone)를 Western electric 705-A를 사용했을 때(ANSI 1969 기준)는 19 $\mathrm{dB}$ 가 된다고 한다. 그러나 수화기를 Telephonic TDH-39나 TDH-49률 상용하여 측정한 것 은 $20 \mathrm{~dB}$ 라고 하며 수화기의 구조(공기함량) 에 따라 달라진다. 허용범위는 $3 \mathrm{~dB}$ 즉 $17 \mathrm{~dB}$ 에서 $23 \mathrm{~dB}$ 범위라고 한다. 즉 $\mathrm{ISO}(1964)$ 기준 으로는 $19.5 \mathrm{~dB}(20 \mathrm{~dB})$ 라고 하며 이수치는 ANSI(1969)기준과도 일치한다. 이와 같이 수 화기의 구조에 따라 달라진다. 우리 나라 언어 로 검사한 정상인의 SRT는 김 ${ }^{1)}$ 은 $26.7 \mathrm{~dB}$, 노 ${ }^{5)}$ 는 $27.8 \mathrm{~dB}$, 소 등은 $27.0 \mathrm{~dB}$, 신 ${ }^{10)}$ 은 $26.6 \mathrm{~dB}$, 최 ${ }^{15)}$ 는 $27.9 \mathrm{~dB}$, 김 ${ }^{3)}$ 은 $28.7 \mathrm{~dB}$ 로 상호간에 큰 차이가 없다. 이 수치는 회화음역 즉 500,10 00 , 및 $2000 \mathrm{~Hz}$ 의 평균순음역치에 $10 \mathrm{~dB}$ 를 더 한 음압이 대체적으로 어음청취역치가 되며 동시에 $\mathrm{SRT} 0 \mathrm{~dB}$ 가 된다.

\section{8. 어음명료도검사(語音明瞭度檢查 speech discrimination test)}

어음을 인식하는 능력검사 즉 명료도점사 (discrimination test; articulation test)이다. 본 검사에 사용하는 어음은 주로 단음절(單音節 monosyllabic word)이며 2음절, 문장 (文章 sentence) 등도 사용하고 있다.

검사용 단어는 어음청취역치 검사와 같이 일상생활에서 흔히 쓰이는 낱말이라야 하고 표 2 와 같이 한 표에 50 개 단어로 하고 각 표마다 각 음소(音素 phoneme)의 출현빈도와 난이도 가 균등하도록 편성한다. 즉 각 단어의 모음 (母音 vowel) 중 단모음(單母音)과 중모음(重 母音)을 가진 단어가 균등하게 혼합되어 있는 단어를 선택하며 각 단어는 그 발음할 때의 음압이 발성상(發馨上) 균둥(均等)한 단어 (phonetically balanced word; PB word)를 사 용한다.
검사방법은 어음청취역치검사와 같이 검사 법을 충분히 설명하고 연습검사를 거쳐 본 검 사를 하며 연습검사에서 사용한 어음 표는 본 검사에서는 사용하지 않는다.

청력계(audiometer)에 전원을 넣고 잠시 동 안 기다려 정상가동되도록 가열 (warming up) 시킨 다음 녹음테이프에 이미 녹음되어 있는 $1000 \mathrm{~Hz}$ 를 재생시켜 VU meter가 “0”이 되도록 조절한다. 하강법으로는 녹음된 50 개 단어를 들게 하여 들은 데로 마이크(microphone)로 복창시키거나 미리 종이를 주어 쓰게 한다. 복 창한 것은 검사자가 수화기로 듣고 정답을 계 산하고 종이에 쓴 것은 검사가 끝 난 후 그 백분율을 계산한다. 각 표마다 $10 \mathrm{~dB}$ 씩 낮추어 가면서 검사하여 각 음압에 따른 정답의 백분 율을 그림 1 과 같이 어음청력도(語音聽力滴 speech audiogram)에 기록한다. 각 표의 강도 를 아주 약하게 하면 $0 \%$ 가 될 것이고 강하게 하면 명료도가 좋아져 $100 \%$ 에 이를 것이다. 이와 같이 가장 좋은 명료도를 최고명료도(最 高明瞭度 maximal discrimination score; PB $\max$.)라고 한다. 정상청력에서는 대체적으로 어음청취역치(語音聽取閥値 SRT)에 $40 \mathrm{~dB}$ 를 더한 음압에서 최고명료도에 달한다. 그러나 순음청력역치 $40 \mathrm{~dB}$ 에서 벌써 최고명료도에 도달하는 예가 많다. 전음성난청(傳音性難聽 conductive hearing loss)은 어음청력도의 곡선 이 우측으로 이동하나 그 곡선의 형태는 정상 명료도와 같다. 후미로성난청 예컨대 청신경종 (褔神椫腫 acoustic neuroma)같은 것은 순음청 력검사는 비교적 양호하나 어음명료도는 30 $40 \%$ 정도 밖에 되지 않는 수도 있다. 또 전음 성난청에서는 음을 강하게 하면 명료도도 그에 따라 좋아진다. 그러나 감각신경성난청(感學神 經性難聽 sensorineural hearing loss) 특히 후 미로성난청(後迷路性難聽 retrocochlear hearing loss)에서는 최고명료도가 저하하여 70 $80 \%$ 이하 일 때가 많으며 음을 더 강하게 하면 그 명료도곡선이 오히려 하강하는 현상이 나 타나는데 이 현상을 rollover phenomen이라고 하며 순음청력검사에는 없는 현상으로 음이 
들리기는 하나 이해를 못하는 것으로 난청부 위의 감별진단에 중요한 지표가 된다(그림 1 참조).

9. 쾌적음량과 허용역치(most comfortable loudenss and tolerance level)

어음청력검사에서 쾌적음량(快適音量 most comfortable loudness)과 허용역치(許容閾値 tolerance level)는 보청기(補聽器 hearing aid) 처방에 필요한 사항이다. 쾌적음량은 문장(文 章 sentence)으로 검사하며 강도를 높여가면서 가장 편하고 들기 좋은 음량으로 생각될 때 신호하도록 하여 결정한다. 허용역치는 불래역 치(threshold discomfort; TD) 혹은 불래음량 역치(uncomfortable loudness level; UCL; $\mathrm{ULL}$ )이라고도 하며 불쾌할 정도로 큰 음량을 말한다. 허용역치 즉 불쾌역치에서 어음청춰역 치(SRT)를 뺀 값이 음량(역학)범위(dynamic range)라고 하며 환자가 보청기에 사용 가능한 음량이다. 즉 보청기를 제작할 때 이 음량범위 에서 출력되도록 해야 한다.

\section{0. 톡수 어음청력검사(special speech} audiometry)

1) 왜곡어음 명금도검사(歪曲語音 明瞭度 檢查, distorted speech audiometry)

어음을 일부 찌그러지게 변조(變調)시킨 단 어로 명료도검사를 하는 것이다. 즉 일부 주파 수를 예컨대 $500 \mathrm{~Hz}$ 이하 저음역이나 $1200 \mathrm{~Hz}$ 이상 고음역을 여과(濾過 filtration)시켜 왜곡 시키거나 발음 속도를 달리해서 1 분간의 전달 단어 수를 150 에서 350 단어로 증가시켜서 찌 그러지게 변조하거나 아니면 중간 절단스위치 를 사용하여 $1 / 20$ 초간 단절시킨 단어률 듣게 하는데 정상인은 $50 \mathrm{~dB}$ 강도로 들게 한 명료 도는 $80 \%$ 정도이다.

2) 양이합성능검사(biaural speech integration test)

한 어음을 양 귀에 동시에 혹은 시간차를 두고 좌우 분리하여 들렸을 때 혹은 한 단어를 두개로 절단하여 한 부분은 우측 나머지 부분
은 좌측 귀로 듣게 하면 청각중추로의 뇌간교 차부 즉 상올리브핵 (superior olivery nucleus) 이상의 중추에서 양 거에서 들은 것을 융합 (融合) 가산기능(加算機能)으로 한쪽 거로 들 었을 때보다 더 이해가 쉬운 원리를 응용한 것이다. 즉 한 쪽 거로 들은 명료도 보다 양측 거로 들은 명료도가 좋지 못하면 뇌간교차부 이상의 중추에 병변이 있다고 추정한다.

3) 양 귀 분리능점사(biaural separation or interaural discrimination test)

서로 다른 단어를 양 귀에 동시에 들렸을 때 정상인은 양 거에서 동시에 듈리는 단어를 분 리 판별할 수 있다. 분리 청취가 잘 되지 않거 나 어느 한쪽에서 들은 것 만을 이해하는 것은 고위중추나 피질(cortex)에 이상이 있다고 추 정한다.

11. 어음청력검사에 영향을 미치는 인자 (factors affecting speech audiometry)

1) 검사단어의 강도(loudness), 주파수 특 성(frequency), 주파수 변조 등의 검사어음에 관한 물리적 조건에 따라 영향을 미친다.

2) 언어학상의 특성(linguistic nature) 즉 검사어음이 방언(dialect)이냐, 전후관계를 암 시하는(contextual cues) 단어인가, 친숙도(familiarity)가 큰 단어인가에 따라 달라진다.

3) 검사시의 조건변화 검사어음을 제시하 는 방법, 속도, 반응양식, 점사어음의 발음과 말하는 모양의 차, 그리고 피검자의 잔청정도 (殘聽程度), 경험유무, 교육정도, 지능, 협조심 등에 따라 달라 질 수 있다.

4) signal/noise ratio( $\mathrm{S} / \mathrm{N}$ ratio) 즉 검사 어음이 잡음보다 $12 \mathrm{~dB}$ 강할 때 감각신경성난 청에서는 명료도가 불량해진다. 차폐음(masking noise)도 잘못하면 많은 영향을 준다.

5) 단어의 주파수성분에 따라 달라진다. 즉 족 단어를 고주파수를 통과시키고 저주파 수를 차단(high pass filter)하면 그 명료도가 $90 \%$ 에 이르는 것도 고주파 수를 차단(low pass filter)하면 그 명료도가 $27 \%$ 정도라고 Hirsh et $\mathrm{al}^{20}$ )이 지적하였다. 임상적으로 
는 고음장애환자가 많으므로 여과(filter)와 변 조(distortion)의 두 가지 인자가 동시에 작용하 는 수가 있다.

\section{요 약}

어음청력검사는 순음청력검사와 더불어 감각 신경성난청의 감별진단에 많은 동음을 준다. 즉 어음명료도가 $80 \%$ 를 넘지 않고 rollover현상이 있으면 감각신경성난청 중에서도 후미로성난청 을 의심하고 순음청력검사는 비교적 양호한데 어음명료도가 $30 \sim 40 \%$ 이하이면 청신경초종을 의심한다. 기타 변조어명료도검사, 양이합성능 검사, 음양이분리능검사로는 고위 중추나 피질 의 장애를 감별진단 할 수 있다. 어음명료도검 사로서 알 수 있는 허용역치(tolerance level)와 역학범위(dynamic range)는 보청기장착에 가용 범위(可用範圍)의 한 지표를 제시한다.

그 외에 어음청력검사용 어음의 선택기준, 어 음청취역치와 어음명료도 검사방법을 설명하고 어음청력검사 성적에 미치는 인자와 임상적 기 여도에 관하여 약술하였다.

\section{참 고 문 헌}

1) 김창준 : 유의단음절 어음 표에 의한 정상 및 각 난청별 어음청력과 순음청력과의 상관관계에 관한 연구. 부산의대잡지 16 : 1 16, 1976.

2) 김영명 - 최생이·강태형, 등 : 어음청력검 사방법과 한국어음청력검사표에 관한 연 구 - 제 1 보 - 정싱인의 검사. 한이인지 21 : 831 835, 1978.

3) 김종민 : 어음명료도 검사를 위한 우리말 어음표의 규격화에 대한 연구. 한이인지 $18: 29 \sim 36,1975$.

4) 김홍기 : 어음청취역치와 순음청력검사의 상관관계에 관한 연구. 한이인지 24 : $543 \sim 545,1981$.
5) 노관택 : 우리말 회화어음의 청각적 연구 최신의학 $18: 12 \sim 18,1975$.

6) 명광현 : 어음의 명료도 및 오청상. 한이인 지 $15: 9 \sim 14,1972$.

7) 박찬일 - 한태희 : 한국어 어음청력검사 단 음절어음표의 규격화에 대한 연구. 한이인 지, $28: 269 \sim 279,1985$.

8) 이규식 · 권요한 · 홍종선 - 백준기 : 어음청 력검사에 의한 수청명료도와 오청경향. 한 이인지 $20: 235 \sim 243,1977$.

9) 소진명 - 박성준 · 은재희 등 : 양양격단어 와 유의단음절어에 대한 통계학적 고찰. 한이인지 $13: 31 \sim 34,1970$.

10) 신규식 : 한국 정상인에 대한 speech audiometry에 관하여. 한이인지 $3: 1 \sim 3,19$ 60.

11) 유방환 : 선택된 우리말 100 단어 음절의 명료도와 오청상에 관한 연구. 한이인지 $15: 19 \sim 54,1972$.

12) 유병회 : 선택된 우리말 100 어음의 오청상 의 구성음소에 관한 연구. 한이인지 15 : 1 18, 1972.

13) 윤병용 - 권용진 · 고의경 등 : 주파수변조 어음청력검사에 관한 임상적 연구. 한이인 지 $29: 425 \sim 435,1986$.

14) 이종담 : 한국어음 청력검사 어집에 관한 기초적 연구. 제 1 편 오청에 관하여. 제 2 편 명료도에 관하여. 한이인지 $19: 1 \sim 25,19$ 76.

15) 최창수 : 한국어 어음명료도와 그 어음청 력검사표 선택에 관한 임상적 고찰. 해군 의무단잡지 $6: 1,1961$.

16) 한태희 - 박찬일 : 한국어 어음청력검사 단 음절어음표의 규격화에 대한 연구. 한이인 지 $24: 265 \sim 273,1981$.

17) 함태영 : 한국어음 청력검사어표와 명료도 검사성적에 관한 연구. 카톨릭의대 논문집 5, 6:31 36, 1962.

18) Charles W. Cummings: Otolaryngology Head and Neck Surgery, 2nd Ed. Mo- 
sby-Year Book Inc. St. Louis, Baltimore, Boston, Chicago, London, Philadelphia, Sydney, Toronto. pp. 147 164, 1992.

19) Davis H. and Silvermam SR.: Hearing and Deafness, 4th Ed. New York: Holt, Rinehart and Winston, 1960.

20) Hirsh IJ. Reynolds Eg. and Joseph M. : Intelligibility of different speech materials. J. Acoustic Soc. Am. 26:530 538, 1954.

21) Kalikow DN. Stevens KN. Elliot LL. :
Development of a test of speech intelligibility in noise using sentence materials with controlled word predictability. J. Acoust Soc. Am. 61 : 1337 1351, 1977.

22) Michael M. Paparella and Donald A. Shumrick : Otolaryngology 3rd Ed. W. B. Saunders Comp. Philadelphia, London, Toronto, Montreal, Sydney, Todyo. pp. 175 201, 1991. 